\title{
Diurnal Fluctuation of Leukocyte G6PD Activity. A Possible Explanation for the Normal Neutrophil Bactericidal Activity and the Low Incidence of Pyogenic Infections in Patients with Severe G6PD Deficiency in Israel
}

\author{
BARUCH WOLACH, MEIR ASHKENAZI, RAMI GROSSMANN, RONIT GAVRIELI, \\ ZIVA FRIEDMAN, NAVA BASHAN, AND DIRK ROOS \\ Department of Pediatrics, Central Laboratories and the Laboratory for Leukocyte Function, Meir General \\ Hospital, Sapir Medical Center, Kfar Saba, The Sackler School of Medicine, Tel Aviv University, 61390 \\ Israel [B.W., M.A., R.Gr., R.Ga., Z.F.], Research Laboratory, Soroka Medical Center, Beer-Sheva, Israel \\ [N.B.], and Sanquin Research at CLB, and Landsteiner Laboratory, Academic Medical Center, University \\ of Amsterdam, Amsterdam, The Netherlands [D.R.]
}

\begin{abstract}
ABST glucose-6-phosphate dehydrogenase (G6PD) deficiency is commonly encountered in the Mediterranean basin. Nevertheless, concomitant clinical evidence of white blood cell G6PD deficiency is extremely rare in Israel. This study sought to assess simultaneously levels of G6PD activity in polymorphonuclear leukocytes (PMN) and in red blood cells (RBC) of patients with G6PD deficiency, including full-term newborn infants. In PMN, the correlation between G6PD activity, hexose monophosphate shunt activity, and superoxide anion release was evaluated. In G6PD-deficient patients, a parallel and significantly decreased G6PD activity was found in neutrophils (range of activity $0-4.5$ $\mathrm{IU} / 10^{6} \mathrm{PMN}$ ) and erythrocytes (range of activity $0-1.8 \mathrm{IU} / \mathrm{g} \mathrm{Hb}$ ), compared with healthy controls (5-23 IU/10 6 PMN and 2.4-6.4 $\mathrm{IU} / \mathrm{g} \mathrm{Hb}$, respectively). A positive correlation was found in PMN between the levels of G6PD activity, hexose monophosphate (HMP) shunt activity, and superoxide anion release $(p<0.01)$. Nevertheless, all patients' bactericidal activity of neutrophils remained in the range of healthy controls. Although many epi-
\end{abstract}

sodes of acute hemolytic anemia were recorded, no increased incidence of pyogenic infections was observed in any group of patients investigated. Neutrophil and erythrocyte G6PD levels were re-assessed in some of these patients several times a day. A significant diurnal fluctuation of the enzyme activity was found. It is speculated that the patients produce fluctuating daily quantities of NADPH, sufficient to initiate the neutrophil respiratory burst and to achieve normal bactericidal activity, necessary to prevent the development of microbial infections. (Pediatr Res 55: 807-813, 2004)
Abbreviations
G6PD, glucose-6-phosphate dehydrogenase
CGD, chronic granulomatous disease
HMP, hexose monophosphate
RBC, red blood cell
WBC, white blood cell
PMN, polymorphonuclear

Erythrocyte G6PD deficiency, mainly manifested by hemolytic anemia induced by oxidative stress to the $\mathrm{RBC}$, is a relatively common worldwide disorder (1). The G6PD gene is located on the $\mathrm{X}$ chromosome, leading to the clinical manifestations of the disease being usually confined to hemizygous men, although female carriers with marked expression of the

Received September 4, 2002; accepted May 28, 2003.

Correspondence: B. Wolach, M.D., Deparment of Pediatrics, Meir General Hospital, 44281 Kfar Saba, Israel; e-mail: baruchw@clalit.org.il

DOI: 10.1203/01.PDR.0000120680.47846.47 aberrant allele may also suffer (2). This entity is encountered among various ethnic groups in Israel as well (3-5).

G6PD catalyzes the reduction of NADP to NADPH, the first step of the HMP pathway. Phagocytic leukocytes use NADPH as a substrate for the NADPH-oxidase enzyme, which contributes to the killing of ingested microorganisms by subjecting them to highly toxic reactive oxygen species (ROS) and bringing about myeloperoxidase-catalyzed halogenation of proteins. Recently, it was reported that the killing activity of neutrophils is enhanced in yet another way by the NADPH oxidase (6). Generation of superoxide $\left(\mathrm{O}_{2}{ }^{-}\right)$within the phagosome that contains the ingested microorganisms induces an influx of 
cations to compensate for the negative charge of the superoxide. The resulting increase in $\mathrm{K}^{+}$ions leads to liberation of proteases from the anionic matrix of the granules that have fused with the phagosome, and an influx of protons is necessary for the creation of an optimal $\mathrm{pH}$ for the enzymatic activity of these proteases. Thus, both oxygen-dependent and oxygen-independent mechanisms are activated by the NADPH oxidase, both crucial for the killing process $(6-8)$.

The clinical expression of G6PD deficiency includes a wide range of disturbances, such as hemolysis induced by drugs or infections, leukocyte disorders, and organ dysfunctions (1). Patients with severe leukocyte G6PD deficiency have been reported to be susceptible to pyogenic infections when levels of the enzyme are $<5 \%$ of the normal activity (9-19). Mediterranean G6PD-deficient subjects were found to have reduced G6PD activity in their leukocytes with accelerated decay of the enzyme under stress $(1,10)$. In some areas of the Middle East, a significant incidence in pyogenic infections was reported in RBC-G6PD-deficient patients (20), although no PMN-G6PD levels were assessed in these patients. In Israel, there has been one report of a fatal bacterial infection in a patient of Ethiopian origin, in which concomitant congenital agranulocytosis (Kostmann's disease) was diagnosed as well (21).

The aim of the present study was to better understand the reason for the negligible incidence of pyogenic infections in Israeli patients with severe G6PD deficiency and the normal function of their neutrophils with deficient enzymatic levels. Simultaneously, the correlation between the levels of G6PD in erythrocytes and neutrophils was assessed in different age groups. We searched for G6PD-deficient newborn infants to learn whether this condition plays an aggravating factor in their known immune-suppressed state $(22,23)$.

\section{PATIENTS AND METHODS}

The study group included 33 patients of different ages with erythrocyte G6PD deficiency (enzyme activity levels $<1.8$ $\mathrm{IU} / \mathrm{g} \mathrm{Hb}$ ) and 32 age-matched healthy subjects. Patients with another associated illness were excluded from the study. The patients were divided into three different age groups with corresponding controls: 9 jaundiced newborn infants $(2-30 \mathrm{~d}$ old), 9 children ( $2-12$ y old), and 15 adults ( $18-54$ y old). All patients were Sephardic-oriental Jews or of Arabic origin. Careful patient histories of pyogenic infections were recorded. All patients were clinically healthy at the time of the investigation. No other abnormalities than G6PD deficiency were detected in the jaundiced newborn infants.

PMN and RBC G6PD activities were usually assayed once, but in 12 adults G6PD activities were assessed again within 1-8 wk. In nine healthy controls and in nine G6PD-deficient subjects, the erythrocyte and PMN enzyme activities were determined at three different times on one day $(0800,1300$, and $1800 \mathrm{~h}$ ).

PMN-G6PD levels and PMN bactericidal activity were measured in parallel. Bactericidal activity was investigated in the PMN of 9 newborn infants, 9 children, and 15 adults and in the corresponding controls. HMP shunt activity and simultaneous assessment of superoxide anion release were determined in the
PMN of 14 subjects with PMN-G6PD deficiency and in those of 14 healthy controls.

The study has been approved by the Medical-Ethical Committee at Meir General Hospital, Sapir Medical Center, Kfar Saba, Israel. Informed consent was obtained from all patients.

PMN isolation. A 10-mL blood sample was obtained by venipuncture from adults and children and a $5-\mathrm{mL}$ sample from newborn infants, who were simultaneously studied for their neonatal jaundice. PMN were isolated from heparinized blood by dextran sedimentation and density separation, as described by Böyum (24). After hypotonic red cell lysis, the PMN were resuspended in solutions appropriate for the various assays.

G6PD activity. PMN- and RBC-G6PD enzyme activities were measured spectrophotometrically by monitoring (at 340 $\mathrm{nm}$ ) the rate of reduction of $\mathrm{NADP}^{+}$to NADPH in hemolyzed erythrocytes or sonicated PMNs (25). The enzyme activity was assessed immediately after the cell separation.

Activity of HMP shunt. HMP shunt activity was determined by oxidation of glucose- $1-{ }^{14} \mathrm{C}$. Using glucose- $1-{ }^{14} \mathrm{C}$ as the substrate, cells release $1 \mathrm{~mol}$ of ${ }^{14} \mathrm{CO}_{2}$ for each mol of glucose oxidized. ${ }^{14} \mathrm{CO}_{2}$ is trapped in the center well by hyamine hydroxide as hyamine $-{ }^{14} \mathrm{CO}_{3}$, and the radioactivity is then measured by scintillation spectrometry (26). PMN were suspended in Krebs-Ringer-phosphate (KRGP) buffer $\left(10^{6}\right.$ cells/ $\mathrm{mL})$ with $2 \mathrm{mM}\left[{ }^{14} \mathrm{C}\right]$-glucose $(0.5 \mu \mathrm{Ci} / \mathrm{mL})$ and $1 \mathrm{mM}$ methylene blue. The cells were incubated in sealed tubes with a central well containing filter paper impregnated with $200 \mu \mathrm{L}$ of hyamine hydroxide. After $1 \mathrm{~h}$ of incubation at $37^{\circ} \mathrm{C}, 0.5 \mathrm{~mL}$ of $2 \mathrm{~N} \mathrm{H}_{2} \mathrm{SO}_{4}$ was added to stop the reaction and to release ${ }^{14} \mathrm{CO}_{2}$ from the solution. The tubes were subsequently agitated for another $30 \mathrm{~min}$. The filter paper was removed and placed in vials filled with a toluene-based scintillation fluid, and radioactivity was determined in a scintillation spectrometer (Tricarb, Packard Instruments, Downers Grove, IL, U.S.A.).

Superoxide anion release. Superoxide anion release by PMN was determined with the ferricytochrome $c$ reduction technique, in which superoxide dismutase-inhibitable cytochrome $c$ reduction is taken as an index of superoxide production (27). PMN were suspended in KRP buffer, at a concentration of $2.5 \times 10^{6} / \mathrm{mL}$, and incubated at $37^{\circ} \mathrm{C}$ with $60 \mu \mathrm{M}$ ferricytochrome $c$ (Sigma Chemical, St. Louis, MO, U.S.A.). To initiate the reaction, fMLP (formyl-methionyl-leucylphenylalanine) at $10^{-7} \mathrm{M}$ was added. After $15 \mathrm{~min}$, the reaction was stopped by the addition of cold $N$-ethyl-maleimide. Identical reaction mixtures were simultaneously monitored in the presence of superoxide dismutase (Sigma Chemical). The OD of the supernatants was measured at $550 \mathrm{~nm}$. The results of triplicate tests were averaged, and the superoxide anion release calculated using the Massey extinction coefficient.

Bactericidal activity. Quantitation of maximal bactericidal capacity was conducted in triplicate (28). PMN were suspended in PBS- $0.2 \%$ glucose- $1 \%$ bovine albumin, at a concentration of $1 \times 10^{7}$ cells $/ \mathrm{mL}$. Bacteria were freshly grown before each experiment and allowed to enter an early stationary phase $\left(18 \mathrm{~h}\right.$ at $\left.37^{\circ} \mathrm{C}\right)$.

The final concentration of bacteria was calculated by spectrophotometry at $590 \mathrm{~nm}$. A suspension of PMN was incubated with bacteria (Escherichia coli, 025 wild type, or Staphylococ- 
cus aureus 502A (ATCC 27217) at ratios 1:1, 1:5, and 1:10, and with $10 \%$ (vol/ $/ \mathrm{vol}) \mathrm{AB}$ serum, at $37^{\circ} \mathrm{C}$ for 0,30 , and 90 min, with continuous shaking. The PMN were lysed with distilled water; the suspensions were diluted and plated in triplicate on broth agar plates for $24 \mathrm{~h}$ at $37^{\circ} \mathrm{C}$.

The effect of serum and PBS on the bacteria was evaluated $(<2 \%$ at $90 \mathrm{~min})$, the colonies were counted, and the decrease in colony formation was calculated relative to the control.

Statistical analysis. The statistical analysis was performed with the $t$ test, the Mann-Whitney program, and the linear regression coefficient.

\section{RESULTS}

Patients with erythrocyte G6PD deficiency were evaluated for PMN-G6PD activity. The levels of G6PD activities of erythrocytes and neutrophils in patients and controls are shown in Table 1. Patients with erythrocyte G6PD deficiency disclosed a parallel neutrophil G6PD deficiency, although the percentage residual G6PD activity in the PMN was generally higher than in the RBC.

We reassessed the enzyme levels of G6PD in RBC and in PMN of 12 adult patients during $8 \mathrm{wk}$ and found the enzyme levels to be consistently reduced (data not shown). Additionally, we assessed the RBC and PMN enzyme activity at three different time points during the same day in 18 adults ( 9 patients and 9 controls). Each assay was performed in quintuplicate, and the inter-assay variation was $3-10 \%$. At the different times, the G6PD enzyme showed a wider range of fluctuation in the PMN than in the RBC. Diurnal fluctuation of G6PD levels was evident in PMN and RBC in healthy controls (Table 2). This diurnal fluctuation was also demonstrated in the PMN-G6PD-deficient patients but not in those patients with G6PD-RBC deficiency in whom the G6PD activity was almost absent at all sampling points (Table 2). The degree of fluctuation in PMN-G6PD activity was found at a similar extent in patients and controls. To exclude a possible inhibitory effect on the G6PD activity, the sonicated neutrophil extracts of patients

Table 1. G6PD activity in neutrophils and erythrocytes of patients and controls

\begin{tabular}{|c|c|c|c|c|}
\hline & \multicolumn{2}{|c|}{ Patients } & \multicolumn{2}{|c|}{ Controls } \\
\hline & $\begin{array}{c}\text { PMN } \\
\text { (IU/10 } 10^{6} \text { cells) }\end{array}$ & $\begin{array}{c}\mathrm{RBC} \\
(\mathrm{IU} / \mathrm{g} \mathrm{Hb})\end{array}$ & $\begin{array}{c}\text { PMN } \\
\text { (IU/10 cells) }\end{array}$ & $\begin{array}{c}\mathrm{RBC} \\
(\mathrm{IU} / \mathrm{g} \mathrm{Hb})\end{array}$ \\
\hline \multirow[t]{3}{*}{ Adults } & $\begin{array}{l}1.1 \pm 0.35^{\mathrm{a}} \\
(0-23 \%)^{\mathrm{b}}\end{array}$ & $\begin{array}{c}0.41 \pm 0.16 \\
(0-38 \%)\end{array}$ & $14.1 \pm 1.27$ & $2.92 \pm 0.23$ \\
\hline & $(0-4.5)^{\mathrm{c}}$ & $(0-1.8)$ & $(8-20)$ & $(2.4-4.8)$ \\
\hline & $(15)^{\mathrm{d}}$ & $(15)$ & (13) & (13) \\
\hline \multirow[t]{3}{*}{ Children } & $\begin{array}{l}1.1 \pm 0.45 \\
(0-33 \%)\end{array}$ & $\begin{array}{c}0 \\
(0 \%)\end{array}$ & $9.9 \pm 0.89$ & $3.4 \pm 0.35$ \\
\hline & $(0-4)$ & & $(5.5-12)$ & $(2.4-6.4)$ \\
\hline & (9) & (9) & (10) & (10) \\
\hline \multirow[t]{3}{*}{ Newborn infants } & $\begin{array}{c}2.05 \pm 0.33 \\
(0-13 \%)\end{array}$ & $\begin{array}{r}0.56 \pm 0.2 \\
(0-27 \%)\end{array}$ & $10.9 \pm 1.96$ & $12.5 \pm 0.31$ \\
\hline & $(0-3)$ & $(0-1.6)$ & $(5-23)$ & $(3.2-6)$ \\
\hline & (9) & (9) & (9) & (9) \\
\hline
\end{tabular}

${ }^{\mathrm{a}}$ Mean $\pm \mathrm{SE}$.

${ }^{\mathrm{b}}$ Percentage of simultaneous normal control.

${ }^{\mathrm{c}}$ Range.

${ }^{\mathrm{d}}$ Number of patients. and controls were mixed, and the enzymatic activity was recorded. No inhibitory effect was found.

The methylene-blue-stimulated HMP shunt activity and the superoxide anion release of PMN cells were significantly lower in the PMN of G6PD-deficient patients than in healthy controls $(p \leq 0.01)$ (Table 3 ). A significant positive correlation was found between the levels of PMN G6PD activity, the HMP shunt activity $(r=0.76, p<0.01)$ (Fig. $1 A)$, and the superoxide anion generation $(r=0.75, p<0.01)$ (Fig. 1B).

The bactericidal assay, performed simultaneously with the G6PD activity assay, showed that those patients with severe PMN-G6PD deficiency (PMN-G6PD activity $<5 \%$ of normal) had a normal bactericidal activity, even when the cells were challenged with increased bacteria to PMN ratio. Results were similar with E. coli (Fig. 2) and S. aureus, after incubation of 60 min (patient versus control: $0.9 \pm 0.09$ versus $0.8 \pm 0.1 \mathrm{log}$ decrease of colonies, respectively; N.S.). No correlation between G6PD levels and the rate of bacteria killing was found, even in those patients with PMN-G6PD levels of 0, although a positive correlation was found between superoxide production and PMN-G6PD levels (Fig. 1B). This indicates that alternative mechanisms for bacterial killing may be present beside the respiratory burst.

Likewise, no differences were observed in the PMN bactericidal activity between newborn infants with normal neutrophil G6PD levels and the corresponding group with PMNG6PD deficiency (Fig. 2), although the bactericidal activity of all newborn infants was significantly lower than that observed in older children and adults $(p<0.001)$. The superoxide production of neonatal neutrophils was found to be significantly lower in the nine neonates with neutrophil G6PD deficiency than in the eight neonates with normal enzymatic levels $\left(15.5 \pm 7.1\right.$ versus $47.7 \pm 9.5 \mathrm{nmol} / 10^{7}$ cells $/ 5 \mathrm{~min} ; p<$ 0.001). Further, as previously reported (29), the neutrophil superoxide production of healthy neonates was found to be significantly higher than that observed in healthy adults $(47.7$ \pm 9.5 versus $33.5 \pm 8.6 \mathrm{nmol} / 10^{7}$ cells $/ 5 \mathrm{~min} ; p<0.01$ ).

In the present study, the 24 children and adults with complete RBC-G6PD deficiency experienced 17 episodes of acute hemolysis, and no history of recurrent, severe, or opportunistic bacterial/fungal infections was recorded in the chart of those with concomitant severe leukocyte G6PD deficiency (enzyme level $<5 \%$ of normal). No evidence of hemolytic disease, metabolic disorders, or infectious diseases was detected in the jaundiced newborn infants during their first year of life.

\section{DISCUSSION}

It is well known that the heterogeneous pattern of expression of G6PD deficiency leads to different manifestations in various tissues (1). The different clinical expression of the disease in various areas of the world most probably corresponds to the various mutations that determine the variations in the enzyme structure and activity, as reported by Beutler $(1,2,30)$ and others $(31,32)$. In case of mutations that render the mutant enzyme unstable, RBC, with their long survival of $120 \mathrm{~d}$ and their lack of new protein synthesis, will end up with hardly any G6PD activity left, whereas leukocytes, and especially neutro- 
Table 2. G6PD activity in 18 subjects assessed three times a day

\begin{tabular}{|c|c|c|c|c|c|c|}
\hline \multirow[b]{2}{*}{ Subjects } & \multicolumn{3}{|c|}{ PMN (IU/10 cells) } & \multicolumn{3}{|c|}{$\mathrm{RBC}$ (IU/g Hb) } \\
\hline & $0800 \mathrm{~h}$ & $1300 \mathrm{~h}$ & $1800 \mathrm{~h}$ & $0800 \mathrm{~h}$ & $1300 \mathrm{~h}$ & $1800 \mathrm{~h}$ \\
\hline \multicolumn{7}{|l|}{ Patients } \\
\hline 1 & 0 & 4 & 0 & 0 & 0.2 & 0 \\
\hline 2 & 2 & 2 & 0 & 0 & 0 & 0 \\
\hline 3 & 1 & 0 & 1 & 0 & 0 & 0 \\
\hline 4 & 0 & 0 & 2 & 0 & 0 & 0.2 \\
\hline 5 & 3 & 2 & 5.5 & 0 & 0 & 0 \\
\hline 6 & 3 & 2.5 & 3.5 & 0 & 0 & 0 \\
\hline 7 & 3.5 & 3.5 & 4.5 & 0 & 0 & 0 \\
\hline 8 & 4 & 3.5 & 4 & 0 & 0 & 0 \\
\hline 9 & 4 & 3.5 & 3 & 0 & 0 & 0 \\
\hline \multicolumn{7}{|l|}{ Controls } \\
\hline 1 & 22 & 15 & 7 & 5.94 & 2.40 & 2.80 \\
\hline 2 & 10 & 6 & 6 & 4.75 & 2.80 & 2.80 \\
\hline 3 & 16 & 21 & 6 & 5.15 & 5.90 & 2.80 \\
\hline 4 & 25.3 & 26.7 & 33.9 & 2.00 & 2.18 & 2.45 \\
\hline 5 & 16.3 & 19.5 & 22.2 & 2.46 & 3.05 & 4.31 \\
\hline 6 & 17.2 & 22.5 & 23.4 & 2.65 & 1.50 & 3.17 \\
\hline 7 & 15 & 18 & ND & 2.70 & 2.18 & ND \\
\hline 8 & 18.5 & 18.5 & 24 & 2.37 & 1.78 & ND \\
\hline 9 & 18.5 & 15 & 17 & 1.98 & 2.18 & 1.98 \\
\hline
\end{tabular}

Table 3. Oxidative metabolism of polymorphonuclear leukocytes of children and adults

\begin{tabular}{lccr}
\hline \multicolumn{1}{c}{ Parameter } & Stimulation & $\begin{array}{c}\text { Patients } \\
(n=14)\end{array}$ & \multicolumn{1}{c}{$\begin{array}{c}\text { Controls } \\
(n=14)\end{array}$} \\
\hline HMP pathway activity & Methylene blue $(-)$ & $1.55 \pm 0.3$ & $2.33 \pm 0.6$ \\
$\left(\mathrm{nmol} / 10^{7}\right.$ cells $\left./ \mathrm{h}\right)$ & Methylene blue $(+)$ & $3.8 \pm 0.9^{*}$ & $6.2 \pm 1.1$ \\
$\begin{array}{l}\text { Superoxide production } \\
\left(\mathrm{nmol} / 10^{7} \text { cells } / 5 \mathrm{~min}\right)\end{array}$ & fMLP & $14.1 \pm 9.3^{*}$ & $33.5 \pm 8.6$ \\
\hline
\end{tabular}

$* p<0.01$ as compared with controls.

phils, with their short survival time of about $2 \mathrm{~d}(8-10 \mathrm{~h}$ in the circulation) and their capacity of continuous protein synthesis, will succeed in maintaining a reasonable level of G6PD activity. However, in cases of mutations that decrease the enzymatic activity of G6PD, all tissues will suffer equally.

Severe leukocyte G6PD deficiency is a rare disorder, which has been reported to predispose patients to suffer from severe pyogenic infections, although less frequent and less severe than those found in patients with CGD $(11,16-19)$. This predisposition is due to the fact that G6PD reduces $\mathrm{NADP}^{+}$to NADPH, which is used by the neutrophil NADPH oxidase to generate superoxide $\left(\mathrm{O}_{2}^{-}\right)$, a precursor molecule for bactericidal compounds. In addition, the NADPH oxidase enzyme is also instrumental in liberating and activating proteases involved in the bactericidal activity (6).

In the present study, we investigated 33 Israeli patients with severe G6PD deficiency. We first determined the correlation between G6PD activity in RBC and PMN. We then evaluated the effect of PMN-G6PD deficiency on the hexose monophosphate shunt activity, superoxide generation, and bactericidal capacity. Finally, we determined the effect of the G6PD deficiency on the clinical manifestations of the patients.

Correlation between erythrocyte and leukocyte G6PD activity levels. The Israeli patients with erythrocyte G6PD deficiency showed a parallel enzyme reduction in the leukocyte G6PD activity, although to a different extent (Table 1). These findings are in accordance with reports of other investigators
A.

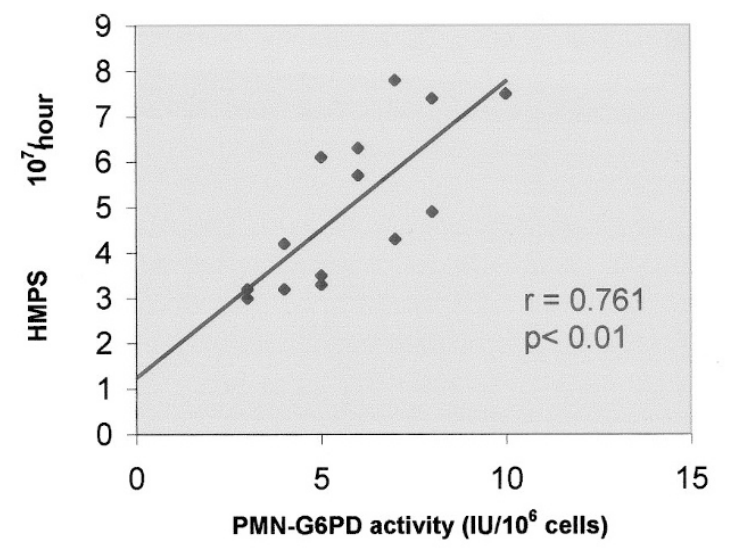

B.

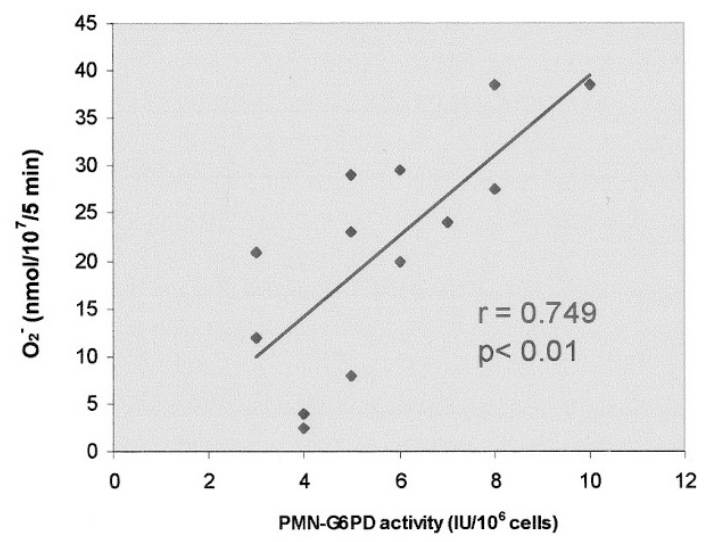

Figure 1. (A) Correlation between PMN-HMP shunt activity and G6PD activity $(n=14)$. $(B)$ Correlation between PMN-superoxide anion release and G6PD activity $(n=14)$. 
A.

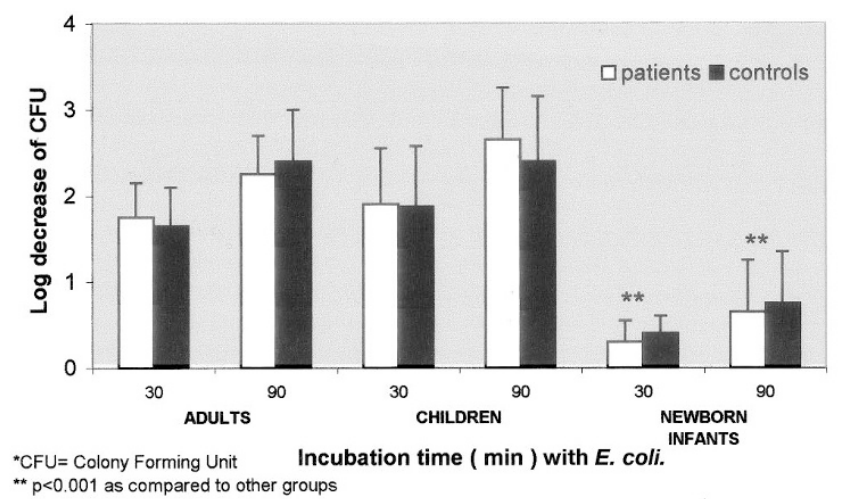

B.

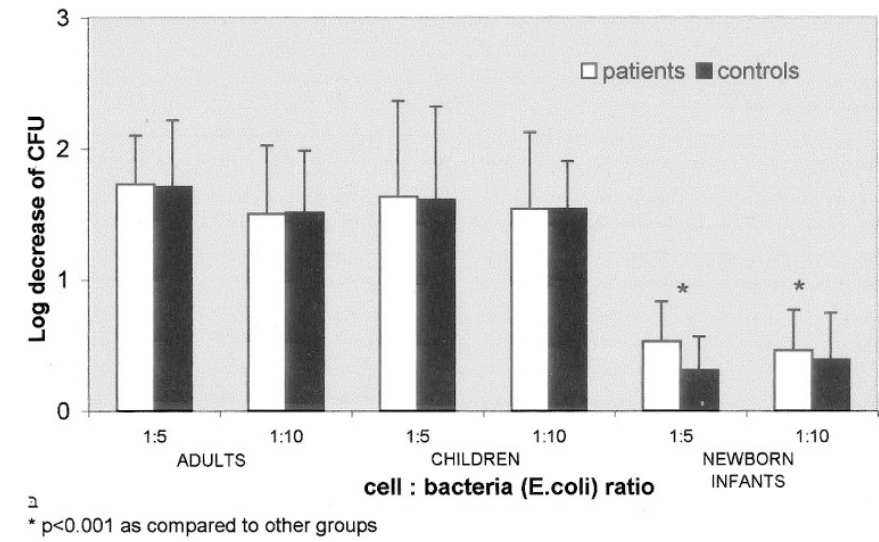

Figure 2. (A) Bactericidal activity of PMN from G6PD-deficient patients and healthy controls: 15 adult patients ( 10 controls), 9 children patients ( 9 controls), and 9 newborn patients ( 8 controls). The PMN/bacteria ratio was 1:10. (B) Bactericidal activity as in $A$, but with PMN/bacteria ratios of 1:5 and 1:10. Incubation time $30 \mathrm{~min}$. Mean $\pm \mathrm{SD}$

$(1,10,33)$. Leukocyte and erythrocyte enzyme activities showed a diurnal fluctuation pattern with unique characteristics for each. This diurnal variation in G6PD activity in leukocytes and erythrocytes was found in healthy and in PMN-G6PDdeficient patients (Table 2). Enzymatic diurnal fluctuation was previously reported in red blood cells (34). In contrast to the healthy population, G6PD-deficient patients showed invariably low, nonfluctuating enzyme levels in the erythrocytes, but their neutrophils exhibited a wide range of enzymatic activity. The reason for the enzymatic fluctuation is not clear. Fluctuation of G6PD levels could be part of the enzymatic fluctuation as that seen in NADPH (35) as a result of feedback activation and inhibition of glycolytic enzymes, especially phosphofructokinase (36). Indeed, these enzyme activities could have fluctuated as a result of a variable ATP utilization, a step that precedes G6PD activity. The degree of fluctuation in PMNG6PD activity was found to be similar in patients and controls. This fact indicates that there is a basic feature of variation in the normal enzyme activity that is not a result of the deficient state.
Correlation between PMN-G6PD activity levels and phagocytic function. The positive correlation found between PMN-G6PD activity levels, the hexose monophosphate shunt activity (Fig. $1 A$ ), and the superoxide production by neutrophils (Fig. $1 B$ ), is consistent with the known role G6PD plays in the NADPH generation and its association with the oxidase activity. The availability of NADPH for the oxidase (as substrate) is essential for the killing of microorganisms by phagocytes (12-19).

Unexpectedly, the bactericidal killing by the neutrophils from PMN-G6PD-deficient patients was found to be normal (Fig. 2), even when enzyme activity levels were $<1 \%$ of control. Even at increased bacteria-to-cell ratios, the bactericidal activity remained normal. These findings are in accordance with those reported by Roos et al. (18) in a Dutch patient. We hypothesize that the normal bactericidal activity could be related to the diurnal fluctuating levels of the leukocyte enzyme activity, which might be sufficient to generate enough NADPH for adequate superoxide anion release by the phagocytes. Alternatively, it could be that there are other sources of NADPH than the HMP shunt, such as hydrogen transfer from NADH to $\mathrm{NADP}^{+}$.

As we previously reported $(29,37,38)$, the bactericidal activity of healthy newborn infants was found to be significantly lower than that of older children and adults (Fig. 2; $p<$ $0.001)$. Nevertheless, no differences were observed between the group of healthy newborn infants and the corresponding group with neutrophil G6PD deficiency. The superoxide production by neutrophils from G6PD-deficient neonates was found to be significantly lower than that of the healthy newborns $(p<0.001)$. In turn, healthy infants had significantly higher superoxide production than healthy adults, as reported in previous studies $(39,40)$.

As derived from the findings of our study, it seems that additional factors rather than the superoxide production determine the bactericidal activity. On the one hand, the population of children and adults with severe PMN-G6PD deficiency, despite decreased superoxide production, disclosed a normal bactericidal activity; on the other hand, newborn infants with overproduction of superoxide anions had significantly decreased microbicidal activity compared with older children and adults. This decreased microbicidal activity is probably the outcome of impaired phagocytosis due to neonatal cell skeleton rigidity, as shown in cell polarization studies of neonatal neutrophils (41). Further, this skeletal abnormality certainly contributes to the known defective neutrophil and monocyte chemotaxis in newborn infants (29). Additionally, recent studies have shown that oxygen-independent mechanisms play a key role in the killing process. One of these is the bactericidal/ permeability-increasing protein (BPI), which selectively binds to Gram-negative bacteria and induces their death. The ability to release BPI was reported to be lower in newborn infants than in adult neutrophils $(42,43)$.

Correlation between PMN-G6PD deficiency and pyogenic infections. In this study, patients with leukocyte G6PD deficiency (even those with extremely low levels of PMNG6PD) had no more pyogenic infections than did healthy controls. This lack of pyogenic infections could be ex- 
plained by the normal bactericidal activity recorded in all patients. Our findings are in contrast with those of Mallouh and Abu-Osba (20), who observed an increased incidence of bacterial infections in 200 Saudi children with erythrocyte G6PD deficiency. It seems that the G6PD Mediterranean type is not homogeneous and may represent an assortment of similar but distinct variants.

\section{CONCLUSION}

In this Mediterranean study, our cohort of patients with severe erythrocyte G6PD deficiency showed recurrent and severe episodes of hemolytic anemia, with no increased incidence of bacterial infections. The neutrophils from these patients showed normal bactericidal activity in vitro, which supported the clinical observations. On the other hand, the normal bactericidal activity is in discordance with the reduced NADPH and superoxide generation. Diurnal fluctuating levels of PMN-G6PD activity were shown in this study and could be related to oscillations of feedback activation and inhibition of glycolytic enzymes in the PMN. Our results suggest that the rapid neutrophil turnover provides enough cells with sufficient production of NADPH for achieving an effective respiratory burst. Moreover, there might be an alternative source of NADPH or a compensatory nonoxidative bactericidal mechanism that could be actively involved in the killing of microorganisms. It is well known that these mechanisms are not sufficient in patients with CGD and occasionally in patients with extreme lack of leukocyte G6PD activity.

As previously stated, the clinical expression of G6PD deficiency is different in the various parts of the world. It could well be that there is a different enzyme expression in the patients from this study as in those from other origin, including other areas of the Mediterranean basin. The enzyme could vary in activity and in its stability, and both effects could result in different clinical expressions. Complementary studies should be performed to identify the genetic basis and the molecularbiochemical properties of the Israeli variants.

Acknowledgment. The authors thank Navah Jelin for the statistical analysis of the data.

\section{REFERENCES}

1. Beutler E 1994 Glucose-6-phosphate dehydrogenase deficiency. Blood 84:3613-3636

2. Beutler E 1990 The genetics of glucose-6-phosphate dehydrogenase deficiency. Semin Hematol 27:137-164

3. Zaidman JL, Leiba H, Scharf S, Steinman I 1976 Red cell glucose-6-phosphate dehydrogenase deficiency in ethnic groups in Israel. Clin Genet 9:131-133

4. Szeinberg A, Sheba CH, Adam A 1958 Selective occurrence of glutathione instability in red blood cell corpuscles of the various Jewish tribes. Blood 13:1043-1053

5. Kurdi-Haidor B, Mason PJ, Berrebi A, Ankra-Badu G, Al-Ali A, Oppenheim A, Luzzatto L 1990 Origin and spread of the glucose-6-phosphate dehydrogenase variant (G6PD-Mediterranean) in the Middle East. Am J Hum Genet 47:10131019

6. Reeves EP, Lu H, Jacobs HL, Messina CGM, Bolsover S, Gabella G, Potma EO, Warley A, Roes J, Segal AW 2002 Killing activity of neutrophils is mediated through activation of proteases by $\mathrm{K}^{+}$flux. Nature 416:291-297

7. Anderson M, Zasloff M 1999 Antimicrobial peptides: complementing classical inflammatory mechanisms of defense. In: Gallin J, Snyderman R (eds) Inflammation: Basic Principles and Clinical Correlates, 3rd Ed. Lippincott Williams \& Wilkins, Philadelphia, pp 1279-1292

8. Levy O 2000 Antimicrobial proteins and peptides of blood: templates for novel antimicrobial agents. Blood 96: 2664-2672
9. Wolach B, Baehner RL, Boxer LA 1982 Review: Clinical and laboratory approach to the management of neutrophil dysfunction. Isr J Med Sci 18:897-916

10. Ramot B, Fisher SH, Szeinberg A, Adam A, Sheba CH, Gafni D 1959 A study of subjects with erythrocyte glucose-6-phosphate dehydrogenase deficiency. II. Investigation of leukocyte enzymes. J Clin Invest 38:2234-2237

11. Newburger PE, Malawista SE, Dinauer MC, Gelbart T, Woodman RC, Chada S, Shen Q, van-Blaricom G, Quie PG, Curnutte JT 1994 Chronic granulomatous disease and glutathione peroxidase deficiency, revisited. Blood 84:3861-3869

12. Cooper MR, DeChatelet LR, McCall CE, LaVia MF, Spurr CL, Baehner RL 1972 Complete deficiency of leukocyte glucose-6-phosphate dehydrogenase with defective bactericidal activity. J Clin Invest 51:769-778

13. Mamlok RJ, Mamlok V, Mills GC, Daeschner III CW, Schmalstieg FC, Anderson DC 1987 Glucose-6-phosphate dehydrogenase deficiency, neutrophil dysfunction and chromobacterium violaceum sepsis. J Pediatr 111:852-854

14. Vives Corrons JL, Feliu E, Pujades MA, Cardellach F, Rozman C, Carreras A, Jou JM, Vallespi MT, Zuazu FJ 1982 Severe glucose-6- phosphate dehydrogenase (G6PD) deficiency associated with chronic hemolytic anemia, granulocyte dysfunction, and increased susceptibility to infections: description of a new molecular variant (G6PD Barcelona). Blood 59:428-434

15. Rodey GE, Jacob HS, Holmes B, McArthur JR, Good RA 1970 Leukocyte G6PD level and bactericidal activity. Lancet 1:355-356

16. Baehner RL, Johnston Jr RB, Nathan DG 1972 Comparative study of the metabolic and bactericidal characteristics of severely glucose- 6 phosphate dehydrogenasedeficient polymorphonuclear leukocytes and leukocytes from children with chronic granulomatous disease. J Reticuloendothel Soc 12:150-169

17. Gray GR, Klebanoff SJ, Stamatoyannopoulus G, Austin T, Naiman C, Yoshida A, Kliman MR, Robinson GCF 1973 Neutrophil dysfunction, chronic granulomatous disease and non-spherocytic haemolytic anemia caused by complete deficiency of glucose-6-phosphate dehydrogenase. Lancet 2:530-534

18. Roos D, van Zwieten R, Wijnen JT, Gomez-Gallego F, de Boer M, Stevens D, Pronk-Admiraal CJ, de Rijk T, van Noorden CJF, Weening RS, Vulliamy TJ, Ploem JE, Mason PJ, Bautista JM, Khan PM, Beutler E 1999 Molecular basis and enzymatic properties of glucose-6-phosphate dehydrogenase volendam, leading to chronic nonspherocytic anemia, granulocyte dysfunction, and increased susceptibility to infections. Blood 94:2955-2962

19. Van Bruggen R, Bautista JM, Petropoulou T, de Boer M, van Zwieten R, GómezGallego F, Belohradsky BH, Hartwig NG, Mason PJ, Roos D 2002 Deletion of leucine-61 in glucose-6-phosphate dehydrogenase leads to chronic nonspherocytic anemia, granulocyte dysfunction, and increased susceptibility to infections. Blood 100:1026-1030

20. Mallouh AA, Abu-Osba YK 1987 Bacterial infections in children with glucose-6phosphate dehydrogenase deficiency. J Pediatr 111:850-852

21. Iancovici-Kidon, Sthoeger D, Abrahamov A, Wolach B, Beutler E, Gelbart T, Barak Y 2000 A new exon 9 glucose-6-phosphate dehydrogenase mutation (G6PD "Rehovot") in a Jewish Ethiopian family with variable phenotypes. Blood Cells Mol Dis 26:567-571

22. Wolach B 1997 Neonatal sepsis: pathogenesis and supportive therapy. Semin Perinatol 21:28-38

23. Greenough A 1996 Bacterial sepsis and meningitis. Semin Neonatol 1:147-159

24. Böyum A 1968 Separation of leukocytes from blood and bone marrow. Scand J Lab Invest 97:7

25. Betke K, Beutler E, Brewer GJ, Kirkman HN, Luzzato L, Motulsky AG, Ramot B, Siniscalco M 1967 Standardization of procedures for the study of glucose-6phosphate dehydrogenase. Report of a WHO scientific group. World Health Organ Tech Rep Ser 366:1-53

26. Newburger PE, Pagano JS, Greenberger JS, Karpas A, Cohen HJ 1980 Dissociation of opsonised particle phagocytosis and respiratory burst activity in an Epstein-Barr virus-infected myeloid cell line. J Cell Biol 85:549-557

27. Rister M, Baehner RL 1977 Effect of hyperoxia on superoxide anion and hydrogen peroxide production of polymorphonuclear leukocytes and alveolar macrophages. Br J Haematol 36:241-248

28. Clawson CC, Repine JE 1976 Quantitation of maximal bactericidal capability in human neutrophils. Lab Clin Med J 88:316-327

29. Wolach B, Sonnenschein D, Gavrieli R, Chomsky O, Pomeranz A, Yuli I 1998 The neonatal neutrophil inflammatory responses: correlation of light scattering with cell polarization, chemotaxis, superoxide release and bactericidal activity. Am J Hematol $157: 8-15$

30. Beutler E, Kuhl W 1990 The NT 1311 polymorphism of G6PD: G6PD Mediterranean mutation may have originated independently in Europe and Asia. Am J Hum Genet 47:1008-1012

31. Kirkman HN, Riley Jr HD, Crowell BB 1960 Different enzymatic expressions of mutants of glucose-6-phosphate dehydrogenase. Proc Natl Acad Sci U S A 46:938944

32. Rozenszajn LA, Joseph D 1974 The isoenzyme patterns of glucose-6-phosphate dehydrogenase in blood cells, bone marrow and other human tissues. Biochim Biophys Acta 364:38-44

33. Chan TK, Todd D, Wong CC 1965 Tissue enzyme levels in erythrocyte glucose-6phosphate dehydrogenase deficiency. J Lab Clin Med 66:937-942

34. Brok-Simoni F, Ashkenazi YE, Ramot B, Holtzman F 1976 The diurnal rhythm of enzymes in human red cells. Br J Haematol 32:601-607

35. Petty HR, Kindzelskii AL 2001 Dissipative metabolic patterns respond during neutrophil transmembrane signaling. Proc Natl Acad Sci U S A 98:3145-3149

36. Goldbeter A 1996 Biochemical Oscillations and Cellular Rhythms. Cambridge University Press, Cambridge, UK

37. Wolach B, Carmi D, Gilboa S, Satar M, Dolfin T, Schlesinger M 1994 Some aspects of the humoral immunity and the phagocytic function in newborn infants. Isr J Med Sci 30:331-335 
38. Ben Dor M, Ashkenazi M, Rozenzajn LA, Wolach B 1988 Bactericidal activity of phagocytic cells in neonates. Harefuah 114:332-335

39. Wolach B, Gavrieli R, Pomeranz A 2000 Effect of granulocyte and granulocyte macrophage colony stimulating factors (G-CSF and GM-CSF) on neonatal neutrophil functions Pediatr Res 48:1-5

40. Yamazaki M, Matsuoka T, Yasui K, Komiyama A, Akabana T 1988 Increased production of superoxide anion by neonatal polymorphonuclear leukocytes stimulated with chemotactic peptide. Am J Hematol 27:169-173

41. Wolach B, Ben Dor M, Chomsky O, Gavrieli R, Shinitzky M 1992 Improved chemotactic ability of neonatal polymorphonuclear cells induced by mild membrane rigidification. J Leuk Biol 51:324-328

42. Levy O, Martin S, Eichenwald E, Ganz T, Valore E, Caroll SF, Lee K, Goldmann D, Thorne GM 1999 Impaired innate immunity in the newborn: newborn neutrophils are deficient in bactericidal/permeability-increasing protein. Pediatrics 104:1327-1333

43. Nupponen I, Turunen R, Nevalainen T, Peuravuri H, Pohjavuori M, Repo H, Andersson S 2002 Extracellular release of bactericidal/permeability-increasing protein in newborn infants. Pediatr Res 51:670-674 